\section{Содержание и доброкачественность дубильных веществ у трех видов рода Salix L. в Карелии}

\author{
А. Ю. Фалин ${ }^{1}$ \\ Петрозаводский государственный университет
}

\begin{abstract}
АННОТАЦИЯ
В статье приведены результаты исследований содержания и доброкачественности дубильных веществ (танинов) в коре 3 видов ивы в условиях Заонежского (Karelia onegensis) флористического района Карелии. Проводится их обсуждение. Рассмотрены возможности использования указанного биохимического показателя в качестве таксономического, даны рекомендации по потенциально возможной селекции ив Карелии на таннидность.
\end{abstract}

Ключевые слова: ива, таксономия, танины, внутривидовая изменчивость, селекция.

\section{SUMMARY}

The results of investigation of contents and quality of willow tannins in the bark of 3 Salix L. species in Karelia onegensis floristic region (Republic of Karelia, Russia) are presented. The taxonomy value of this biochemical sign is discussed. The principals of future selection of tannin willows in Karelia are offered.

Keywords: willow, taxonomy, tannin, intraspecific variation, selection.

Дубильные вещества растений (танины, производственное название, используемое в кожевенной промышленности - таниды или танниды) - группа природных полифенолов, способных взаимодействовать с белком кожных покровов - коллагеном, в результате чего образуются структуры, устойчивые к процессам гниения [5]. В промышленных целях используют экстракты из коры дуба, ели, некоторых других растений - таннидоносов. Ивовые танины относят к числу лучших дубителей, а их присутствие в смеси с другими дубителями (например, еловыми) ускоряет процесс и обеспечивает равномерный продуб [15]. В настоящее время в промышленных целях используются также синтетические дубители (синтаны). Тем не менее, из-за сложного химического состава природных танинов создать их искусственные аналоги пока не удается [14]. В связи с истощением сырьевой базы, низкой производительностью и отсутствием перспектив интенсификации заготовок коры в естественных ивняках, в СССР с 1968 года производилась закладка плантаций таннидных ив. (За 1969-1981 годы было создано более 24 тыс. га плантаций; план на 11-ю пятилетку составлял 16,2 тыс. га.) Одновременно (в основном, в южных регионах страны) ве-

${ }^{1}$ Автор - аспирант кафедры лесного хозяйства, сотрудник Ботанического сада ПетрГУ

(C) А. Ю. Фалин, 2003 лись исследования естественных популяций с целью отбора высокотаннидных форм ивы $[11,14]$. Ресурсной оценки ивняков, а также селекционных работ в Карелии не проводилось. (До 1992 года на базе Института леса КарНЦ РАН изучалась возможность использования в кожевенной промышленности отходов окорки ели [2].) В настоящее время, в связи с резким спадом производства и развалом хозяйственных связей, установить производственную заинтересованность в естественных дубителях не представляется возможным. Тем не менее, осторожный прогноз о возрождении интереса к ним по мере выхода страны из экономического кризиса сделать можно.

Следует отметить, что содержание танинов видоспецифично и рассматривалось некоторыми авторами [8] в качестве дополнительной таксономической характеристики видов Salix L., определение которых затруднено в связи с резко выраженным внутривидовым полиморфизмом и относительно легкой их способностью к межвидовой гибридизации.

Цели исследования заключались в установлении содержания и доброкачественности танинов (отношение танины/водорастворимые в экстракте [11]) у трех видов рода Salix L. - Ива в условиях Заонежского флористического района Карелии, ориентировочной оценке изменчивости признака, а также уточнении его хемотаксономической ценности и возможности практического использования при идентификации таксонов. В качестве объекта исследований были выбраны S. caprea L. - Ива козья; S. pentandra L. Ива пятитычинковая; S. myrsinifolia Salisb - Ива мирзинолистная, что обусловлено следующими соображениями. Эти виды представляют группу «дубильных ив» [9], в связи с чем результаты исследований могут быть востребованы производством. В филогенетическом отношении они относятся к различным секциям 2 подродов (из трех) рода Salix L. [12] (табл. 1); появляется возможность проверки значимости признака в таксономическом отношении.

Взятие материала происходило в южной Карелии, близ села Великая Губа (Медвежьегорский административный район). В соответствии с биогеографическим районированием Карелии, территория относится к Заонежскому [10] или Karelia onegensis [3] флористическому району. Количество исследованных экземпляров: S. pentandra L. - 10; S. myrsinifolia Salisb. - 16; S. caprea L. - 16. Содержание дубителей в коре может варьировать в течение вегетационного периода; различно на уровнях ствола, у особей разного возраста; меняется под влиянием почвенных и климатических условий $[7,8,13]$. Для нивелирования этих факторов предпринимались следующие меры. Тестируемые растения были примерно одного возраста (912 лет), брались в однообразных почвенных условиях (вдоль мелиоративных канав, расположенных на сушенном низинном болоте); кора отбиралась 
Таблица 1

Таксономические особенности видов, задействованных в исследовании

\begin{tabular}{|c|c|c|c|}
\hline Подрод & Секция & Подсекция & Вид \\
\hline Salix & Pentandrae & ---- & S.pentandra L. - Ива пятитычинковая \\
\hline \multirow{3}{*}{ Vetrix } & Nigricantes & ---- & S. myrsinifolia Salisb. - Ива мирзинолистная \\
\cline { 2 - 4 } & Vetrix & Laeves & S.caprea L. - Ива козья \\
\hline
\end{tabular}

одновременно (21-го и 22-го августа 2002 года). Исследуемые особи находились на равном расстоянии друг от друга (около 20 метров). Для идентификации с каждого дерева брался гербарный образец. Кора снималась у основания стволов (методом кольцевого среза); вывешивалась в проветриваемом помещении (сарае) и доводилась до воздушно-сухого состояния. Анализы проводились в аналитической лаборатории Института леса КарНЦ РАН в январе - феврале
2003 г. Содержание дубильных веществ определялось титриметрическим методом [6] (путем титрования перманганатом калия водного раствора танинов в присутствии индигосульфокислоты). Водорастворимые определялись по массе сухого остатка после выпаривания экстракта. Результаты исследований приведены в таблице 2. Для оценки достоверности различий между средними использовался F-критерий Фишера (табл. 3).

Таблица 2

Содержание и доброкачественность танинов в коре исследуемых ив (в процентах от веса абсолютно сухой коры)

\begin{tabular}{|c|c|c|c|c|c|c|c|c|c|}
\hline \multirow{2}{*}{$\begin{array}{l}\text { Вид } \\
\text { ивы }\end{array}$} & \multirow[t]{2}{*}{$\mathrm{n}$} & \multicolumn{4}{|c|}{ Танины, \% } & \multicolumn{4}{|c|}{ Доброкачественность, \% } \\
\hline & & Min & Max & $\mathrm{M} \pm \mathrm{m}$ & $\mathrm{C}, \%$ & Min & Max & $\mathrm{M} \pm \mathrm{m}$ & $\begin{array}{l}\mathrm{C}, \\
\%\end{array}$ \\
\hline $\begin{array}{l}\text { S. pentandra L. - Ива } \\
\text { пятитычинковая }\end{array}$ & 10 & 4,80 & 6,74 & $5,81 \pm 0,23$ & 12,3 & 21,74 & 31,71 & $27,24 \pm 1,03$ & 12,0 \\
\hline $\begin{array}{l}\text { S. myrsinifolia Salisb. - } \\
\text { Ива мирзинолистная }\end{array}$ & 16 & 9,03 & 14,31 & $11,57 \pm 0,42$ & 14,3 & 31,59 & 40,41 & $36,90 \pm 0,69$ & 7,5 \\
\hline S. caprea L. - Ива козья & 16 & 8,2 & 16,6 & $12,54 \pm 0,53$ & 16,7 & 35,54 & 48,48 & $42,36 \pm 0,78$ & 7,3 \\
\hline
\end{tabular}

Таблица 3

Отношение дисперсий (F-критерий Фишера) выборок содержания танинов и их доброкачественности у исследуемых видов, соотнесенное с критическим для 5\%-го уровня надежности

\begin{tabular}{|c|c|c|c|c|}
\hline \multirow{2}{*}{$\begin{array}{l}\text { Вид } \\
\text { ивы }\end{array}$} & \multicolumn{2}{|c|}{ S. pentandra $\mathrm{L}$. } & \multicolumn{2}{|c|}{ S. myrsinifolia Salisb. } \\
\hline & Танины & Доброкачественность & Танины & Доброкачественность \\
\hline \multirow[t]{2}{*}{ S. caprea $\mathrm{L}$. } & $\mathrm{F}=94,56$ & $\mathrm{~F}=140,07$ & $\mathrm{~F}=2,07$ & $\mathrm{~F}=27,53$ \\
\hline & \multicolumn{2}{|c|}{ F кр. $=4,26$} & \multicolumn{2}{|c|}{ F кр. $=4,17$} \\
\hline \multirow[t]{2}{*}{ S. pentandra $\mathrm{L}$. } & & & $\mathrm{F}=107,77$ & $\mathrm{~F}=65,32$ \\
\hline & & & \multicolumn{2}{|c|}{ F кр. $=4,26$} \\
\hline
\end{tabular}

Как видно из данных, не различаются достоверно по содержанию танинов $S$. myrsinifolia Salisb. и S. caprea L. B то же время доброкачественность экстрактов указанных видов неодинакова $(\mathrm{F}=27,53$ при Fкр.=4,17). Коэффициент вариации содержания танинов у $S$. myrsinifolia Salisb. и S. caprea L. по шкале изменчивости, предложенной А. С. Мамаевым [4], соответствует среднему уровню (у $S$. pentandra L. находится на верхней границе низкого уровня). Изменчивость показателя доброкачественности экстрактов варьирует меньше (у S. caprea L. и S. myrsinifolia Salisb. находится на верхней границе очень низкого, а y $S$. pentandra L. - низкого уровня).

Некоторые данные по таннидности видов, полученные в исследованиях других авторов, приводятся в таблице 4 (по В.И. Парфёнову и И.Ф. Мазану [1986]).
Видно, что показатели содержания танинов в исследованной популяции (табл. 2) сравнимы с данными из других регионов (следует иметь в виду, что авторами часто используются различные методы установления таннидности, что может оказывать влияние на сопоставление результатов).

По результатам работы можно сделать вывод о теоретической возможности использования показателя таннидности в таксономических целях (например, при выявлении степени родства секций). Однако, как правило, это относится к более далеким в филогенетическом отношении таксонам. Например, S. pentandra L (секция Pentandrae) дальше с точки зрения внутриродовой системы от $S$. myrsinifolia Salisb. и $S$. caprea L., чем два последних вида друг от друга. 
Таблица 4

Некоторые усредненные показатели таннидности видов, задействованных в исследовании (по [8])

\begin{tabular}{|l|c|}
\hline \multicolumn{1}{|c|}{ Вид ивы } & Таннидность, \% \\
\hline S. pentandra L. & 8,0 \\
\hline S. myrsinifolia Salisb. & 11,0 \\
\hline S. caprea L. & 12,9 \\
\hline
\end{tabular}

Кроме того, влияние множества экзо- и эндогенных факторов затрудняет сравнение. Возможно, внимание следует обратить на показатель доброкачественности экстрактов.

Заготовка коры в производственных масштабах (если она будет возобновлена) может быть совмещена с проведением уходов за мелиоративной сетью. При потенциально возможных селекционных работах в Карелии (как минимум, в южной ее части, во второй половине лета, в богатых почвенных условиях, при использовании для анализа титриметрического метода) следует ориентироваться на особи с содержанием танинов у основания ствола выше $12 \%$ для S. caprea L. и S. myrsinifolia Salisb и 6\% - для S. pentandra L. (последний вид рекомендуется в литературе [11] для создания плантаций на сырых местообитаниях).

Автор выражает благодарность М. А. Коржовой (Аналитическая лаборатория Института леса КарНЦ РАН) за помощь в проведении анализов образцов.

\section{СПИСОК ЛИТЕРАТУРЫ}

1. Бормотов В. И., Нилов В. Н. Таннидность видов Salix L. Архангельской области // Растительные ресурсы. 1987. Т. 23. Вып. 2. С. 234-238.

2. Гелес И. С. и др. Характеристика отходов окорки и некоторые направления их использования // Отходы окорки и некоторые направления их комплексного использования. Петрозаводск, 1984. $169 \mathrm{c}$.

3. Кравченко А. В., Гнатюк Е. П., Кузнецов О. Л. Распространение и встречаемость сосудистых растений по флористическим районам Карелии. Петрозаводск, 2000. 75 с.
4. Мамаев С. А. Формы внутривидовой изменчивости древесных растений (на примере семейства Pinaceae на Урале). М.: Наука, 1972. 284 с.

5. Муравьева Д. А. Фармакогнозия. М.: Медицина, $1981.656 \mathrm{c}$.

6. Оболенская А. В., Ельницкая 3. П., Леонович А. А. Лабораторные работы по химии древесины и целлюлозы. М.: Экология, 1991. 320 с.

7. Оразов О. Э. и др. Динамика содержания танидов в коре некоторых видов p. Salix L. // Растительные ресурсы. 1993. Т. 29. Вып. 1. С. 69-72.

8. Парфенов В. И., Мазан И. Ф. Ивы (Salix L.) Белоруссии. Таксономия, фитоценология, ресурсы. Минск: Наука и техника, 1986. 166 с.

9. Правдин Л. Ф. Дубильные ивы - ценные технические растения // Лесное хозяйство. 1976. № 5. C. 80-82.

10. Раменская М. Л. Определитель высших растений Карелии. Петрозаводск: Государственное издательство Карельской АССР, 1960. 485 с.

11. Сидоров А. И. Таннидные ивы. М.: Лесная промышленность, 1978. 120 с.

12. Скворцов А. К. Ивы СССР. М., 1968. 259 с.

13. Субоч Г. Н. Содержание дубильных веществ у видов Salix L. (Новосибирская область) // Растительные ресурсы. 1988. Т. 24. Вып. 4. С. 610-614.

14. Чумаков В. В. Создание плантаций высокотаннидных ив: Обзорн. информ / ВНИИЦлесресурс Госкомлеса СССР. М.: 1991. 36 с. (Лесоводство, лесоразведение, лесные пользования. Вып. 36).

15. Якадин А. И., Егоров Б. А. Растительные дубительные материалы. М.: Легкая индустрия, 1968. $172 \mathrm{c}$. 